London; and organized by Paul Schwartzkopf. Scientists and industrialists working in the field of powder metallurgy met with physicists and chemists interested in theoretical fundamentals.

The first of the three series of lectures was on Physical and General Metallurgy. F. Skaupy presented Present Views on the Nature of Metals; A. G. Smekal, Ideal and Real Crystals; H. Nowotny, Bonding in Intermetallic Phases; G. M. Schwab, Electron Theory of Mechanical Strength; H. Forestier, Effect of Adsorbed Gases on the Reactivity of Metallic Surfaces; and M. Auwarter, Stability of Inorganic Compounds in High Vacuum. Special attention was centered on the paper by W. Seith on Diffusion in Metals. In this review of modern concepts of diffusion, the author contended that the effect of pore formation attributed to different diffusion rates of the components will undoubtedly enforce a revision of the basic concepts of the diffusion mechanism.

The experimental evidence presented by Seith was supplemented by $\mathrm{H}$. Bückle with color slides. The mechanism of pore formation, that is, the coagulation of vacancies to microscopic pores was of special interest to powder metallurgists since it may be considered as a reversal of the mechanism of pore elimination during sintering. Discussion of this paper made it clear why pore formation by different diffusion rates was not noticed earlier. The existence of the pores, although observed previously, was incorrectly attributed to the original contact boundary. It was the spacer technique of Kirkendall that permitted the demonstration that the location of the pores does not coincide with that of the boundary.

During the series on Hard Metals, R. Fitzer summarized his work at the Technical University Vienna, on the development of high temperature materials by silicizing tungsten and molybdenum. Following this presentation, R. Kieffer demon- strated two types of new heating elements developed at the Metallwerk Plansee. The first type consisted of loops of silicized molybdenum, while the second represented bars of compacted molybdenum silicide. The molybdenum silicide exhibited considerable mechanical strength and resistance to thermal shock, and permitted operating temperatures of $1700^{\circ} \mathrm{C}$. The discussion indicated that this development is expected to play an important part in future developments of furnace construction, particularly in furnaces for the ceramics industry.

Other papers presented were The Ternary System W-C-Co, by J. T. Norton; Preparation of Pure TiC, by G. F. Hüttig; Solid Solubilities at $1250^{\circ} \mathrm{C}$ of Various Carbides in the Bonding Metals Co, Ni, and Fe, by T. Raine and R. Edwards; Systematics of Properties of Hard Metals, by C. Ballhausen; and Ternary Systems $\mathrm{Me}_{1}-\mathrm{Me}_{2}-\mathrm{B}$, and Relative Strength of the Bond Between Transition Metals and Boron, by R. Kiessling.

At the final session, lectures were given by G. J. Comstock and F. H. Clark, Development of High Strength Heat Treatable Products from Alloy Powders; H. S. Cannon and F. V. Lenel, Mechanism of Liquid Phase Sintering; A. Langhammer, Powder Metallurgy as viewed by a Manufacturer of Metal Powder Products; G. Ritzau, Thermoelectric Analysis of the Sintering Mechanism; E. M. Onitsch-Modl, Analysis of Alloy Formation During Sintering by Microhardness Testing; and H. H. Hausner, Effect of Lattice Changes on the Sintering Process.

Speaking for the guests, G. F. Hüttig of the Technical University Graz, thanked Dr. Schwartzkopf for the organization of the Seminar. "The seminar has sintered together the powder metallurgists of the free world to one family," he declared, "and the established close cooperation will undoubtedly largely contribute to further progress in our field."

\title{
AIME Fall Meeting at Centennial of Engineering
}

$\mathrm{T}$ Fall Meeting of the AIME-to be held in conjunction with the Centennial of Engineering -will be held in Chicago. Sessions of interest to members of the Metals Branch will take place Sept. 5 to 9,1952 , and Mining Branch sessions begin September 3. Headquarters hotel will be the Palmer House. A paper on the Growth of AIME by A. B. Parsons will be given Wednesday, September 3 at the Eighth Street Theater.

The Iron \& Steel Div. will hold a session at $2 \mathrm{pm}$ Friday, September 5, in the Crystal Room of the Palmer House. Two papers are scheduled for this session: Developments in Steel Alloys, by Elmer Gammeter, Director of Globe Steel Tubes Co. Laboratories; and A Review of Wide Strip Rolling, by D. S. Holstein, general superintendent of rolling and finishing, Middletown div., Armco Steel Corp.

Friday evening at $6: 30 \mathrm{pm}$, the Chicago Section, AIME, will hold a dinner meeting at the American Bar Assn. headquarters in the Equitable Bldg. E. C. Bain, vice-president, research and technology, U. S. Steel Co., will be the speaker at this meeting.

An AIME Dinner Dance will be held at $7 \mathrm{pm}$ Saturday evening, in the Red Lacquer Room of the Palmer House. The AIME Board of Directors will hold a meeting Sunday afternoon from 2 to $5 \mathrm{pm}$ in the Crystal Room of the Palmer House.

On Monday and Tuesday, September 8 and 9 , although not part of the AIME program, a Mineral Industries Symposium sponsored by the Centennial will be held in the Ballroom of the Hotel Sherman. Clyde Williams, Battelle Memorial Institute, will be chairman for this meeting, and R. J. Anderson, Battelle Memorial Institute will be secretary. After an Introduction by the chairman, the following subjects will be discussed: Exploration for Metals, Petroleum and Water, W. E. Wrather, U. S. Geological Survey; Mining and Quarrying, D. H. McLaughlin, Homestake Mining Co.; Coal Mining, Preparation, and Utilization, J. B. Morrow, Alford Morrow \& Associates; Ore Beneficiation and Hydrometallurgy, O. C. Ralston, U. S. Bureau of Mines; Nonmetallic Materials, J. D. Sullivan, Battelle Memorial Institute; Iron and Steel Production and the Coke Industry, Walther Mathesius, Freyn Engineering Div., Koppers Co., Inc.; Nonferrous Smelting and Refining, R. W. Diamond, Consolidated Mining \& Smelting Co. of Canada, Ltd.; Synergism of Engineering and Petroleum, R. E. Wilson, Standard Oil Co. (Ind.); Role of Metals in Our Economy, Zay Jeffries, General Electric Co.; and a Commentary by Clyde Williams. 